\title{
Legal framework for recycling domestic solid waste in Vietnam: situation and recommendation
}

\author{
Nguyen Khanh Bui ${ }^{1 *}$, Thanh Ly Nguyen ${ }^{1}$, Khanh Duong Phan ${ }^{1}$, and Anh Thu Nguyen ${ }^{1}$ \\ ${ }^{1}$ Graduate Academy of Social Science, 477 Nguyen Trai Street, Hanoi, 10000, Vietnam
}

\begin{abstract}
In recent years, the environmental pollution caused by a large amount of domestic solid waste generated in localities across the country is a challenge that governments of all levels, sectors and localities need to focus on solving. In order to make a substantial change in the domestic solid waste management, improve environmental quality and contribute to improving the quality of people's lives, the Vietnamese Goverment is actively implementing specific activities to strengthen the management and recycle of domestic solid waste throughout the country. Besides, in the current legal documents, there is still a lack of guidance on appropriate technology selection and technical guidance on domestic solid waste collection, storage, treatment and recycle. Solid waste recycling activities are still scattered, spontaneous and lack the management and control of the competent authorities on environmental protection in the locality. The majority of recycling facilities are small in scale, the level of technology investment is not high, the majority of technologies are outdated and the machinery and equipment are obsolete, which causes environmental pollution. This article focuses on the challenges of recycling domestic solid waste in Vietnam. It also provides causes and recommendation to amend and supplement regulations related to recycling domestic solid waste in Vietnam
\end{abstract}

\section{Introduction}

In recent years, along with the socio-economic development, the strong population growth and the rapid urbanization in our country have led to an increase in the amount of solid waste generated, including both the composition and nature of solid waste that has been causing difficulties for waste management and treatment, especially for domestic solid waste which has a significant impact on the environment.

According to the results of the survey and assessment of the Ministry of Natural Resources and Environment (MONRE), currently, the volume of domestic solid waste generated nationwide is more than 61,000 tons/day, of which more than 37,000 tons/day and more than 24,000 tons/day are generated in urban areas and rural areas, respectively (MONRE 2020).

\footnotetext{
${ }^{*}$ Corresponding author: khanhlaw75@yahoo.com
} 
Recently, the management of domestic solid waste in Vietnam has not been applied with the form of integrated management and has not been paid much attention to in terms of solutions to minimize, reuse, recycle and recover energy from waste, as a result, the volume of domestic solid waste to be landfilled is high, thereby not saving the land, and has been a risk of environmental pollution. On the other hand, the separation of solid waste at source only takes place in some localities and has not been replicated nationwide. In addition, the issues of infrastructure, equipment and specific collection facilities for each type of waste are not yet appropriate, leading to inefficient waste separation at source.

Recycling activities are ussually implemented by informal sector, carrried out in households in craft villages with rudimentary technologies, and causing Environmental pollution. Regarding treatment and disposal, nearly $75 \%$ of municipal solid waste (MSW), is still landfilled, mainly in unhygienic dumping sites. Besides the household waste, hazardous waste (HW), plastic, e-waste, and construction and demolition (C\&D) waste are also emerging in Vietnam.

Based on practical results of implementing the regulations related to recycling domestic solid waste in Vietnam shows that besides some positive results (Vietnam Law and Legal Forum (2016), the legal framework for recycling domestic solid waste in Vietnam has revealed the shortcomings and limitations, which need to be amended and supplemented to resolve the current

Environmental challenges in Vietnam.

This review was developed by discussing challenges of recycling domestic solid waste in Vietnam, focus mainly in shortcomings and limitations of laws on recycling domestic solid waste with the data and supported by Ministry of Natural Resources and Environment (MONRE) and Environment and Natural Resources Department of Provinces in Vietnam.

\section{Materials and Methods}

This paper discusses literature review as a methodology and is based on published data of Vietnam Environment Administration, Ministry of Natural Resources and Environment (MONRE) and Environment and Natural Resources Department of Provinces in Vietnam from 2014-2018. This paper uses the comparison and analysis methods to analyzes and compares the provisions of laws related to recycling domestic solid waste.

It shall be noted that environmental data collected mainly official information, omitting an undefined number of pending cases for further investigation. Neither skills, equipment nor integrity variables were available and taken into account for this article.

\section{The challenges of recycling domestic solid waste in Vietnam}

Currently, in Vietnam, the most common technology for domestic solid waste treatment is landfilling, besides, there are composting, burning and recycling. The current waste treatment rate by the treatment methods is as follows: $71 \%$ of total waste (equivalent to 43 thousand tons/day) is treated by landfilling method (excluding waste and ash from compost processing facilities and incinerators); $16 \%$ of total waste (about 9.5 thousand tons/day) is treated at compost processing factories; $13 \%$ of total waste (about 8 thousand tons/day) is treated by incineration method. 


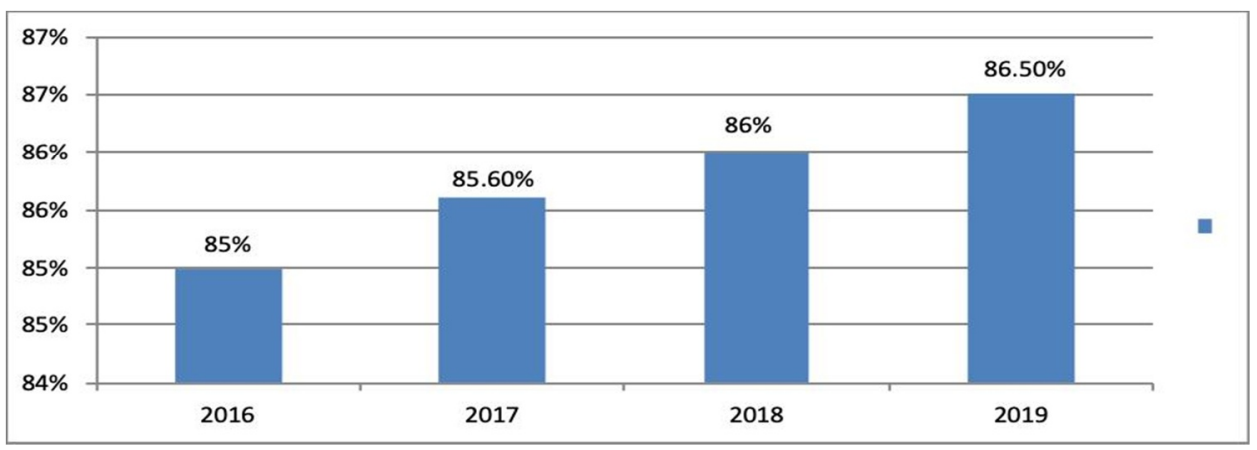

Fig. 1 The rate of domestic solid waste is collected and treated in accordance with standards in the period of 2016 - 2019 (Source: Vietnam Environment Administration, Ministry of Natural Resources and Environment, 2019) (MONRE 2020)

The domestic solid waste treatment technologies being applied (both domestic and foreign technologies) are increasingly diverse, but their actual effectiveness has not been fully assessed. Although a number of domestically- developed technologies have been applied in recent years and brought about certain initial results, these technologies are mostly undertaken by private enterprises, so the improvement of technologies as well as the application in reality still faces many difficulties. Foreign technologies used in Việt Nam face difficulties due to unseparated solid waste at source, high humidity, tropical weather conditions; the amount of received solid waste is lower than the designed capacity or is unstable, the investment capital is quite high, leading to high treatment costs.

In Vietnam, the recycling of metals, paper, and plastic has been conducted from 1960s, mostly for providing the materials for production industry, which was still limited even in term of scale, capacity, and sources. The recycling activities were boomed in 1990s, just after the beginning of Doi Moi process, when the government untied the private sector for economic activities, with the development of "craft villages" (Hai H.T., Quang N.D., Thang N.T., Nam N.H. (2020). Based on Art.3, Circular No. 116/2006/TT-BNN dated December 18 , 2006, providing guidance on implementation of some articles of the Government's Decree No. 66/2006/ND-CP dated July 7,2006, on development of rural professions, "craft villages" means one or more residential areas of villages or other similar residential points in a commune or town that have rural professions producing one or more different types of product and traditional caft villages means craft villages having its traditional profession existed for a long time.

Up to December 2018, according to the new criteria, there were only 2,009 craft villages officially recognized in Vietnam (including 1,134 craft villages and 875 traditional craft villages). The environmental protection obligations of the recycling craft villages are stipulated in Circular No. 31/2016/TT-BTNMT dated October 14, 2016, providing for Environmental protection for industrial clusters, concentrations of business, service providers, craft villages, production commercial and service establishments (MONRE 2020).

Based on published data of Vietnam Environment Administration, Ministry of Natural Resources and Environment and Environment and Natural Resources Department of Provinces in Vietnam from 2014-2019, Vietnam's recycling domestic solid waste is facing great challenges in the coming years, such as:

- Recycling activities are usually implemented by craft villages. The implementation of solid waste management planning in localities is still slow; the mobilization of investment resources for construction of solid waste treatment facilities and plants has many difficulties. The investment in solid waste management and treatment is still inadequate; though many solid waste treatment facilities have been built and operated, their facilities, 
capacity and treatment efficiency have not met the requirements. In particular, many unsanitary landfills and incinerators have not yet met environmental technical standards, causing environmental pollution due to the generation of secondary wastes such as wastewater, gaseous emissions and solid waste.

Almost recycling activities are usually implemented by craft villages. Among these craft villages, there are more than 100 recycling craft villages, with $80 \%$ is metal recycling villages, the others are paper and plastic recycling. The properties of these recycling villages are: (i) not regulated by any specific laws and regulations; (ii) informal sector that uses rudimentary, simple and backward technologies that do not meet technical and environmental protection requirement; (iii) low quality and production efficiency; and (iv) dealing mostly with the domestic scrap, which is normally polluted and not well-sorted. (Hai H.T., Quang N.D., Thang N.T., Nam N.H. (2020).

- The collection and transportation of recycling domestic solid waste are unsuitable. The collection and transportation of recycling domestic solid waste are implemented differently between urban and rural areas, among localities and even among areas within the same locality. In urban areas, the recycling domestic solid waste generated by households is usually collected by the collection units at a certain time, manual vehicles are used by the collectors to transfer waste to the gathering places, from which it is transported to the treatment facilities or transhipment terminals before being moved to the treatment facilities. In rural areas, many localities have self-governing groups and women's unions that collect waste at a certain frequency and transport them to gathering places so that the functional units shall collect, transport and transfer them to the treatment facilities. However, in many cases, waste is not collected or not collected thoroughly, leading to the formation of temporary landfills, causing environmental pollution.

Meanwhile, landfills are often far away from residential areas, which increases transportation costs. Currently, the fees charged upon households and individuals for domestic solid waste collection, transportation and treatment only partially cover waste collection cost; there is not enough money to pay for the cost, as well as to maintain transporting activities; the transportation capacity of some localities is still limited, without specialized equipment and means of transport, resulting in leakage and spillage of waste into the environment.

- Environmental pollution in recycling craft villages will be increased and complicated. However, the environment in recycling craft villages still faces many shortcomings. According to the report on the implementation of environmental protection in craft villages in some localities, the infrastructure facilities for environmental protection in many recycling craft villages have not been invested. Solid waste, sewage, and exhaust gas have not been completely treated, causing adverse impacts on the environment landscape and polluting the air, water and soil environment. Many recycling craft villages (paper, plastic, metal ...) releases a huge amount of solid waste after the production process. This waste is not collected and processed. discharging into public areas, ponds and lakes, clogging drainage systems, seriously polluting surface water, underground water (MONRE 2020).

Up to June 2019, 28/47 recycling craft villages had projects (or plans) for pollution treatment approved by competent authorities; 18/47 recycling craft villages are implementing investment projects; 01 recycling craft village stopped working (MONRE 2020). 


\section{The shortcomings and limitations of laws on recycling domestic solid waste}

Since 2005, the Law on Environmental Protection had stated to encourage the development of clean energy, renewable energy, environmentally friendly products, and reduce, reuse, recycle. The Law on Environmental Protection 2014 has specified the commitment in 8 Articles. Accordingly, many follow-up legal documents such as: Decree of Government, Circular of Ministry of Natural Resources and Environment were issued to clarify and implement the commitment of the law.

In addition, Vietnamese Government issued plenty of strategies (which were approved by Prime Minister's decisions) that supported to recycling domestic solid waste such as: Sustainable Development Strategy of Vietnam period 2011-2020 included a task to build a system of integrated solid waste management, in which solid wastes are classified at source, collected, reused, recycled, and thoroughly treated with appropriate advanced technologies. National Strategy on Environment Protection by 2020, with a vision toward 2030 detailed plenty of measures to enhance cleaner production and reduce, reuse, recycle (3R); National Strategy for General Management of Solid Waste to 2025, with a vision toward 2050 addressed plenty of measures to improve the classification, collection, reduce, reuse, and recycle of solid waste (Hai H.T., Quang N.D., Thang N.T., Nam N.H. (2020).

Based on 10 years of implementation, the laws on recycling domestic solid waste shows that, besides some positive results, the laws has revealed the shortcomings and limitations such as:

- The mechanism and policy on recycling domestic solid waste is not appropriate and synchronized with the Circular Economy. Although the term "Circular Economy" has not been officially used in legislattive documents and policies, many aspects of circular economy have been regulated and supported. They include consuming less raw materials; reducing energy leakages, enhancing the use of renewable energy, limiting the use of fossil fuels; reducing the use of plastic and promoting the use of environmentally friendly products; encouraging reduce, reuse, and recycle (3R); promoting sustainable production and consumption, especially green supply chain and green public procmement. However, some detailed legislation and policies are needed to foster the implementation (Hai H.T., Quang N.D., Thang N.T., Nam N.H. (2020).

Infact, the provisions of the Law have not created a favorable legal framework to recycling domestic solid waste and encourage socialization in some activities of environmental protection.

- The environmental administrative procedures of recycling domestic solid are also fragmented, unconnected and unintegrated. According to current regulations, the State management of solid waste is not uniformly assigned to one agency but to many Ministries and branches involved in the management, including: MONRE, Ministry of Construction (MOC), Ministry of Health $(\mathrm{MOH})$, etc. The overlapping of the State management functions in the field of recycling domestic solid waste leads to many difficulties in the implementation of policies and laws on recycling domestic solid waste management.

In the same project, the investor in the field of recycling domestic solid waste must perform many environmental administrative procedures to get approval from many environmental protection parties, many state agencies such as: the decision on approving the report on environmental impact assessment; Environmental protection plan; the certificate of completion of environmental protection works; permits for discharge of wastewater into water sources; license for industrial emission discharge; Certificate for discarded material import...(MONRE 2020).Therefore, it is necessary to promote the administrative reform and consolidate and link the environmental administrative procedures in the laws on environmental protection in order to implement the Directive. No. 30/CT-TTg dated 
October 30, 2018 of the Prime Minister for improving the quality of administrative procedures at ministries, branches and localities.

- Lack of specific regulation for materials of recycling domestic solid waste. In addition, the current legal documents and polices are fairly broad, and there is a lack of specific regulation for materials of recycling domestic solid waste. For instance, there is no specific regulation for plasticwaste management. Therefore, some plastic waste is, in fact, regulated in municipal solid waste management.

- Lack of guidance on appropriate technology selection and technical guidance on domestic solid waste collection, storage and recycle. In the current legal documents, there is still a lack of guidance on appropriate technology selection and technical guidance on domestic solid waste collection, storage and recycle. Solid waste recycling activities are still scattered, spontaneous and lack the management and control of the competent authorities on environmental protection in the locality. The majority of recycling facilities are small in scale, the level of technology investment is not high, the majority of technologies are outdated and the machinery and equipment are obsolete, which causes environmental pollution. The construction of modern waste treatment facilities and sanitary domestic solid waste landfills requires large investment capital, while many localities do not have enough capital to invest; the mechanisms to promote socialization of domestic solid waste collection and treatment are inadequate and have not yet attracted resources. Many imported solid waste treatment technologies are not suitable with the features of domestic solid waste in Việt Nam (not yet separated at source, low calorific value, high humidity). Meanwhile, domestically-manufactured equipment and technologies for treatment of solid waste are not yet comprehensive or complete and have not been manufactured on an industrial scale; the inspection and supervision process of the construction and operation of some solid waste treatment facilities is yet to be strict, etc.

\section{Recommendations}

Based on challenges of recycling domestic solid waste in Vietnam, the shortcomings and limitations of the laws on recycling domestic solid waste which need to be amended and supplemented with suggestion the following recommendations are proposed:

- Regarding reduce, reuse and recycle of waste approache. Vietnam, as a developing country, has been facing serious problems in the use of natural resources and environmental pollution. Because of that, reduce, reuse and recycle of waste (3R) is considered as one of the decisive approaches to effectively protect the envfronment, contributes to socio economic development in a sustainable way, and is one of the essential tools to ensure the major objectives of the development.

The most important issue now for Vietnam is to build a foundation for a circular economy. This foundation should base on the construction of a unification policy that can integrate different efforts on economic and social development, environmental protection and saving natural resources into one direction. This issue is, surely, needed the support from other countries, to top-down planning of the whole economy of Vietnam, instead of trying to solve waste and environmental problems separately with the development of economy (Hai H.T., Quang N.D., Thang N.T., Nam N.H. (2020).

- Regarding environmental administrative procedures. Currently there are 07 types of environmental permits and discharging sewage into water sources. These permits are related and linked, so it is necessary to consider and integrate 07 types of environmental permits and discharge wastewater into 01 environmental permit to reduce administrative procedures and reduce licensing costs for enterprises.

- Regarding recycling domestic solid waste management. 
The laws on recycling domestic solid waste management must be amended and supplemented to the following contents: (i) Issue the classification of waste, the responsibility to classify for recycling, reuse and treatment to ensure compliance with environmental protection requirements, promoting the circulation and recycling of waste; (ii) Clearly define the responsibilities of waste ownes, domestic solid waste treatment collectors based on "polluters pay" principle; (iii) Clearly define the responsibilities of the provincial People's Committees, the investors, project owners, households and small businesses and services in urban areas for collecting and recycling domestic solid waste up to standards; (iv) Issue the provisions on materials, appropriate technology selection of recycling domestic solid waste./.

\section{References}

1. Communist Party of Vietnam, The 11th Central Executive Committee. Socio-economic Development Strategy 2011-2020 (dated 16 February, 2011). Document of XI Congress of the Party, Hanoi, (2011).

2. Government of Vietnam, Decree 19/2015/ND-CP: Detailing the implementation of a number of articles of the law on environmental protection (dated 14 February 2015), Hanoi, (2015);

3. H.T. Hai, N.D. Quang, N.T. Thang, N.H. Nam Circular Economy: Global Perspective. 425-430 (Springer, Singapore, 2020); DOI: 10.1007/978-981-15-1052-6_22.

4. Ministry of Natural Resources and Environment (MONRE), Five years Summary Report on enforcement of Law on Environment Protection 2014, (2020).

5. Nguyen, N. H, Some economics of climate change adaptation in Vietnam, Ph.D. Thesis, (La Trobe University, Melbourne, Australia, 2014).

6. Prime Minister of Vietnam, Decision No. 432/QD-TTg: Approval of sustainable development strategy of Vietnam period 2011-2020 (dated 12 April, 2012), Hanoi, (2012)

7. Prime Minister of Vietnam, Decision No. 1216/QD-TTg: Approval of national environmental protection strategy by 2020, with a vision toward 2030 (dated 05 September 2012), Hanoi, (2012)

8. Prime Minister of Vietnam, Decision No. 491/QD-TTg: Approval of national Strategy for General Management of Solid Waste to 2025, with a vision toward 2050, Hanoi, (2018)

9. Vietnam Law and Legal Forum, Revised Law on Environmental Protection, 13 (2015);

10. Vietnamese National Assembly's Law Nr. 52/2005/QH11, (2005);

11. Vietnamese National Assembly's Law Nr.60/2010/QH12, (2010);

12. Vietnamese National Assembly's Law Nr.55/2014/QH13, (2014). 